Discourse and Communication for Sustainable Education, vol. 6, pp. 30-49, 2015

\title{
Civic Education for Sustainable Development and its Consequences for German Civic Education Didactics and Curricula of Higher Education
}

\author{
Andreas Brunold \\ University of Augsburg, Germany
}

\begin{abstract}
Since the nineties, the principle of sustainable development has increasingly been adopted by policy makers and civil society in Germany and, of course, in many countries of the world. With the acceptance of this principle, the significance of education for sustainable development (ESD) has also been recognised. Increased awareness of the problems of environmental challenges, globalisation and poverty has meant that the concepts of environmental education, global learning, and education in development policy have been consistently oriented towards more sustainability. This leads to an increased awareness that globalisation processes must be shaped in accordance with the objectives of sustainable development, both nationally and internationally. By encouraging the idea of sustainability to take root in all areas of education systems, the World Decade of Education for Sustainable Development from 2005 to 2014 intended to take significant steps towards greater educational sustainability.

The curricula for civic education for sustainable development and global learning in Germany are, therefore of course, very closely linked to global development and globalisation processes, and because of that, they are to be seen within the mandate of the United Nations educational policy.

The paper shows, that the learning area of global development objectives is structured in an inter-disciplinary and cross-disciplinary manner. It carries the essential features of a domain: a delimited object area, a specific approach to the world, and the reference to a basic teaching concept in the educational policy traditions of one-world or development-policy education and global learning.

Therefore the aim is clear, that these curricula should contribute to the sustainable development goals of the United Nations, towards inclusive and equitable quality education and promote lifelong learning opportunities for all, as it is mentioned in goal number 4 (United Nations, 2014).

Keywords: sustainable development, civic education, UN decade of education for sustainable development, UNESCO, global learning, competencies and curricula of sustainable development education
\end{abstract}


The Concept of Sustainable Development

Sustainable development, as one of the great challenges of our time, is an inclusive concept that applies to all countries of the world; that is, to countries in the northern as much as to those in the southern hemisphere. It is central to all efforts towards the human shaping of the world through globalization.

The original motive for sustainable development becoming an action plan for politics, economy and society had been on the one hand the ecological crisis phenomena and on the other hand the social and economic inequality which had been realized and criticized more and more in the 1960s and 1970s (de Haan, 2004, p. 39). The interdependence between environmental protection and economic development had been accepted, what became the basis for the UN World Commission on Environment and Development (WCED) with its final Brundtland report in 1987 which has defined sustainable development as "development that meets the needs of the present without compromising the ability of future generations to meet their own needs" (Hauff, 1987, pp. 8-46).

The basic philosophy of the concept of sustainable development can be characterized as a doubled integration: On the one hand, as an integration of contents and, on the other hand, as an integration of social participants and actors (Andersen et al., 1999, p. 38). The integration of contents was - because of its conflicts within their goals also called a 'magic square frame of aims' (see Figure 1) of the dimensions of the principles of sustainable development (Brunold, 2004, p. 47).

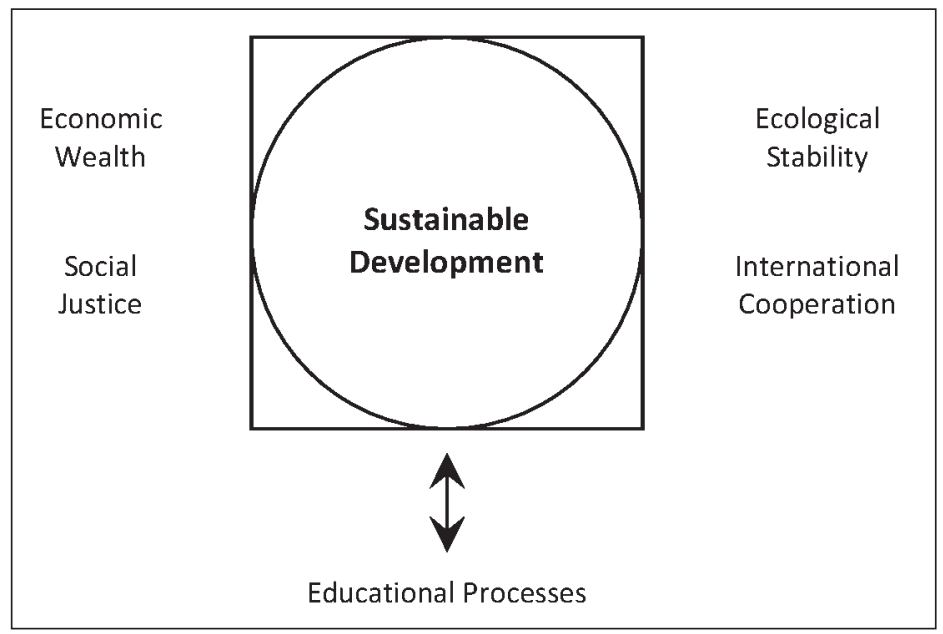

Figure1. Magic Square Frame of Aims (Source: Brunold, 2004, p. 4)

The integration of social forces is caused by the outspreading of educational processes, especially also within higher education institutions. One element of this lies in the system of education, where a big part of our ability to reflect our needs is constructed and fixed. 


\section{From Environmental Education to an Education for Sustainable Development}

In the international context, the history of environmental education extends from the United Nations Conference 'On the Human Environment' in Stockholm in 1972 to the Intergovernmental Conference on Environmental Education in Tiflis in 1977, then further to the UNESCO United Nations Educational Program (UNEP) Conference in Moscow in 1987, to the UNCED in Rio de Janeiro (1992), which marked a change of thinking and in setting public priorities. The Earth Summit in Rio was the starting point for an international appreciation of the sustainable development model and an awareness of the necessity to coordinate social, economic and environmental target components (Federal Ministry of economic cooperation and development, 2007, p. 15).

In contrast to the developed countries of the North, where environmental education has a relatively assured status in the formal education system, immense structural deficits are to be seen in the countries of the South. The classical demand for transfers in technologies therefore, should be understood as transfers of knowledge in a broader sense, by which developed countries also can learn from developing countries and vice versa. Clearly in the area of education, the differences between North and South that emerged during the last century have been increasing. Therefore, knowledge of risk management is important for those countries, where industrialisation is at its inception. The transfer of knowledge between developed and developing countries is, therefore, an absolutely essential instrument for global risk management. This viewpoint is too little known in developed countries and scarcely at all in developing countries, which is why both formal and non-formal education are indispensable prerequisites for creating a change of awareness in the perspective of sustainable development.

The question is: Is it possible to create concepts by multilateral strains which help the national educational politics to focus on the demands of worldwide and interdependent problem phenomena? Several United Nations Conferences and summits since the beginning of 1990s, which can be seen as parts of a "Global Governance architecture" gave some essential contributions towards that goal, for example the United Nations Conference on Environment and Development (UNCED) in Rio in 1992 with the Agenda 21 as action plan for the 21st century, the General Assembly in 2000 with the United Nations Millennium Declaration, the World Summit on Sustainable Development (WSSD) in Johannesburg in 2002 and last but not least the proclamation of the Decade of Education for Sustainable Development from 2005 to 2014. Here the concept of sustainable development became the key of international educational politics (Federal Ministry of economic cooperation and development, 2007, p. 16).

Especially chapter 36 of the Agenda 21 report was primarily focused on the possibility of reorienting education towards sustainable development as a precondition of the necessary changing of public consciousness (Brunold, 2009a, p. 314).

Beyond education of environmental policy an education for sustainable development also requires new cultural, social and economic issues. Unfortunately the concept of sustainable development is still considered on almost all political levels as a program for continuing environmental challenges, like the greenhouse effect, one of the currently most dominating environmental problems. In order to cover the extent of sustainable acting with its global environmental, social, cultural, political and economic problems and their consequences, it is necessary to develop a sensibility and awareness, since such a consciousness in solving problems in general is also a condition for changing 
habits in production and consumption patterns. This aspect of education for sustainable development also leads to an important way of changing harmful learning attitudes in line with sustainability. Therefore this would suggest that criteria for a successful education program are learning processes from immediate experiences in everyday life situations, in connection with orientation in action and the integration of the contents, which has to be taught, in the context of social politics (WBGU, 1999). The road towards greater consciousness of sustainability comes through education, which also also be seen as an important instrument in overcoming problems on a global point of view, just like the Millennium Development Goals show us. Therefore, education for sustainable development has its roots in the history of two distinct areas of interest of the United Nations, education and sustainable development.

\section{The UN Decade of Education for Sustainable Development 2005-2014}

Especially the Johannesburg conference helped to deepen the commitment towards sustainable development on all levels, from the local to the global. After the summit, the United Nations member states committed themselves to the World Decade of Education for Sustainable Development. Resolution 57/254 passed in December 2002, also requesting that UNESCO assumes the task of international coordination, thus signalling that education and learning are at the heart of all approaches to sustainable development. By encouraging the idea of sustainability to take root in all areas of education systems, the World Decade of Education for Sustainable Development from 2005 to 2014 is intended to take significant steps towards greater educational sustainability. Thus the decade aimed to encourage governments, educational institutions, non-governmental organisations, private enterprises, the media and individuals to integrate the concepts of sustainable development into all areas of education (Brunold, 2006, p. 227).

The United Nations Decade of Education for Sustainable Development (DESD) was a complex and far-reaching undertaking. The overall goal of the decade was to integrate the principles, values and practices of sustainable development into all aspects of education and learning. This educational effort should have encouraged changes in behaviour to create a more sustainable future in terms of environmental integrity, economic viability, and a just society for present and future generations.

When UNESCO was requested to lead the decade, it was necessary to develop a so-called draft International Implementation Scheme (IIS), which was the result of extensive consultations with United Nations agencies, national governments, civilian organisations and Non-government Organisations (NGOs), experts and specialists (UNESCO, 2005a). It was presented at the 59th session of the United Nations General Assembly in New York, in October 2004, and then at the 171st and 172nd sessions of the UNESCO Executive Board in Paris in April and September 2005 (UNESCO, 2005b).

The objectives for the DESD were to:

1) facilitate networking, linkages, exchange and interaction among stakeholders in education for sustainable development (ESD),

2) foster an increased quality of teaching and learning in ESD,

3) help countries make progress towards the attainment of the millennium development goals through ESD efforts, and

4) provide countries with new opportunities to incorporate ESD into educational reform efforts. 
The IIS sets out a broad framework for all partners to contribute to the Decade. It was a strategic document that focused primarily on what nations have committed to achieve through the DESD under UNESCO's leadership. The ways countries decided to approach sustainable development were to be closely linked to the values and culture held in these societies. Education for sustainable development focuses, therefore, on underlying principles and values conveyed through education and is more concerned than the other three initiatives with the content and purpose of education, and, more broadly, with learning of all kinds (UNESCO, 2005b, Annex I, p. 4).

The global consultation to prepare the International Implementation Scheme (IIS) led to the identification of the following seven strategies as essential for moving forward by creating regional, national, and sub-national implementation strategies and plans (UNESCO, 2005b, Annex I, p. 11):

1) vision-building and advocacy,

2) consultation and ownership,

3) partnership and networks,

4) capacity-building and training,

5) research and innovation,

6) the use of Information and Communication Technologies (ICTs), and

7) monitoring and evaluation.

All sustainable development programs must consider the three spheres of sustainability: a) environment, b) society (including culture), and c) the economy. Because ESD addresses the local contexts of these three spheres, it will take many forms around the world. Furthermore, education for sustainable development is based on ideals and principles that underlie sustainability, such as intergenerational equity, gender equity, social tolerance, alleviation of poverty, environmental preservation and restoration, conservation of natural resources, and the right to live in just and peaceable societies, which are also part of the Rio Declaration.

In this respect the principle of education for sustainable development is, among others, also a form of political education that should not be neglected as it is based on the understanding that, first and foremost, the industrial nations who are considered to be the main source of environmental and developmental degradation have to start taking action.

UNESCO is building up an instrument for implementing measures and strategies in relation to sustainable development. It is important to ask for the success of the action. Therefore, an international survey (Brunold, 2009b; Ohlmeier \& Brunold, 2015) evaluated the implementation of the DESD in different world regions (Africa, Arab States, Asia and the Pacific, Europe/North America/Central Asia as well as Latin America and the Caribbean). A first result is that the implementation is carried out with different rates in the different regions. While in Asia almost $40 \%$ of the respondents gave positive answers to the question if national plans for the International Implementation Scheme are in action, in all the other regions is only low activity to be seen.

It is agreed in all regions that implementing the goals and strategies of the DESD is primarily a duty of the state and should be carried out by institutions. Barriers are particularly social and economic conflicts, low civic participation as well as a lack of finance and personal staff. Despite of these difficulties people in all world regions have great needs and high expectations regarding education for sustainable development. As main 
areas for education for sustainable development and especially environmental education, democracy education, civic education and global learning are considered.

With time, large discrepancies between regions became apparent concerning the speed at which ESD was being implemented (see Ohlmeier \& Brunold, 2015). It was found that scientific and educational experts responsible for realising the DESD in their respective countries interpreted ESD quite differently. The answers of these experts from different world regions of the DESD to the question: "What does a sustainable or durable development mean to you?" are as following (see Table 1).

Table 1

Meaning of Sustainable or Durable Development (Source: Ohlmeier, 2013, pp. 6-7)

\begin{tabular}{|c|c|c|c|c|c|c|}
\hline & $\begin{array}{l}\text { Africa } \\
(n=62)\end{array}$ & $\begin{array}{l}\text { Arab } \\
\text { States } \\
(\mathrm{n}=52)\end{array}$ & $\begin{array}{l}\text { Asia \& } \\
\text { Pacific } \\
(n=39)\end{array}$ & $\begin{array}{c}\text { Europe and } \\
\text { North America } \\
(\mathrm{n}=173)\end{array}$ & $\begin{array}{l}\text { Latin America } \\
\text { and Caribbean } \\
\quad(\mathrm{n}=150)\end{array}$ & $\begin{array}{c}\text { Total } \\
(\mathrm{n}=476)\end{array}$ \\
\hline Gender equality & 4.2 & 5.9 & 3.5 & 3.9 & 2.0 & 3.5 \\
\hline $\begin{array}{l}\text { Integration of ethnic } \\
\text { minorities }\end{array}$ & 4.6 & 1.7 & 1.8 & 3.1 & 4.7 & 3.5 \\
\hline $\begin{array}{l}\text { The attempt to live } \\
\text { more with nature }\end{array}$ & 8.0 & 7.1 & 9.4 & 5.1 & 4.5 & 5.9 \\
\hline $\begin{array}{l}\text { A programme for mode- } \\
\text { ration and renunciation }\end{array}$ & 0.8 & 1.3 & 0.0 & 1.4 & 2.5 & 1.6 \\
\hline $\begin{array}{l}\text { Education for acting } \\
\text { responsibly in matters } \\
\text { of Environment }\end{array}$ & 15.3 & 16.8 & 16.5 & 14.0 & 11.4 & 13.8 \\
\hline $\begin{array}{l}\text { A programme for peace } \\
\text { and safeguarding of } \\
\text { creation }\end{array}$ & 8.0 & 8.4 & 7.6 & 4.6 & 6.4 & 6.3 \\
\hline $\begin{array}{l}\text { The efficient use of } \\
\text { resources by means of } \\
\text { technological innovations }\end{array}$ & 11.1 & 13.0 & 11.8 & 8.1 & 9.1 & 9.6 \\
\hline $\begin{array}{l}\text { Generation equality/ } \\
\text { responsibility for future } \\
\text { generations }\end{array}$ & 13.0 & 11.3 & 13.5 & 14.8 & 15.9 & 14.5 \\
\hline $\begin{array}{l}\text { Participation in decision- } \\
\text { making by the population } \\
\text { and democratisation of } \\
\text { society }\end{array}$ & 6.5 & 7.6 & 8.8 & 10.5 & 5.5 & 7.9 \\
\hline $\begin{array}{l}\text { The creation of social } \\
\text { and economic justice } \\
\text { from the global point } \\
\text { of view }\end{array}$ & 9.2 & 10.1 & 9.4 & 11.5 & 11.8 & 11.0 \\
\hline $\begin{array}{l}\text { The networking of } \\
\text { economic, social, ecolo- } \\
\text { gical and global aspects }\end{array}$ & 8.4 & 8.8 & 9.4 & 12.5 & 14.6 & 12.0 \\
\hline $\begin{array}{l}\text { A fundamental change of } \\
\text { the consumerist behaviour } \\
\text { ("living good instead } \\
\text { of possessing a lot") }\end{array}$ & 11.1 & 8.0 & 8.2 & 10.2 & 11.5 & 10.3 \\
\hline
\end{tabular}


On the basis of 12 predetermined categories, the authors of the survey found that the Arab States and the countries of Asia and Africa mainly focus on "education for acting responsibly in matters of environment" (16.8\%, 16.5\% and $15.3 \%$ respectively). By contrast, the countries of Latin America, the Caribbean as well as Europe and North America favour "generation equality/responsibility for future generations" (15.9\% and $14.8 \%$ respectively). A striking finding of the study is the fairly low importance ascribed to the "participation in decision-making by the population and democratisation of society", with percentage values varying between $5.5 \%$ and $10.5 \%$, for an average of $7.9 \%$. Worldwide, this politically crucial aspect of SD is ascribed the highest level of importance by the Europeans $(10.5 \%)$.

The international survey also found that experts carry out their projects in a variety of fields (for the following see Table 2). By a considerable margin, the most popular is environmental education (with a total average of $24 \%$ ), led by Latin America and the Caribbean, the Arab states and Africa $(28.5 \%, 26.7 \%$ and $24.3 \%$ respectively). The fields of democracy education and civic education play a much less important role (with total averages of $10 \%$ and $8.9 \%$ respectively), with significant differences among the world's regions (between $6.8 \%$ and $12.1 \%$ and between $4.9 \%$ and $12.4 \%$ respectively). The answers of scientific and educational experts from different world regions of the DESD to the question: "Which fields of action of Education for Sustainable Development are dealt with in projects of your organisation?" are the following (see Table 2).

Table 2

Fields of Action of Education for Sustainable Development (Source: Ohlmeier, 2013, p. 8)

\begin{tabular}{lcccccc}
\hline & $\begin{array}{c}\text { Africa } \\
(\mathrm{n}=62)\end{array}$ & $\begin{array}{c}\text { Arab } \\
\text { States } \\
(\mathrm{n}=52)\end{array}$ & $\begin{array}{c}\text { Asia \& } \\
\text { Pacific } \\
(\mathrm{n}=39)\end{array}$ & $\begin{array}{c}\text { Europe and } \\
\text { North America } \\
(\mathrm{n}=173)\end{array}$ & $\begin{array}{c}\text { Latin America } \\
\text { and Caribbean } \\
(\mathrm{n}=150)\end{array}$ & $\begin{array}{c}\text { Total } \\
(\mathrm{n}=476)\end{array}$ \\
\hline Environment education & 24.3 & 26.7 & 20.3 & 20.5 & 28.5 & 24.0 \\
\hline Global learning & 7.3 & 10.8 & 9.8 & 10.3 & 10.9 & 10.1 \\
\hline Civic education & 4.9 & 10.2 & 9.8 & 12.4 & 5.6 & 8.9 \\
\hline Peace education & 7.8 & 7.4 & 8.3 & 6.3 & 4.0 & 6.1 \\
\hline Democracy education & 12.1 & 11.9 & 6.8 & 8.3 & 11.6 & 10.0 \\
\hline Economic education & 10.2 & 9.7 & 6.8 & 9.5 & 6.7 & 8.6 \\
\hline $\begin{array}{l}\text { Gender mainstreaming } \\
\text { Education for human } \\
\text { rights }\end{array}$ & 11.2 & 4.5 & 8.3 & 6.9 & 6.5 & 7.2 \\
\hline $\begin{array}{l}\text { Development policy } \\
\text { education }\end{array}$ & 10.7 & 8.0 & 7.5 & 8.1 & 8.5 & 8.5 \\
\hline $\begin{array}{l}\text { Intercultural and anti- } \\
\text { racist learning }\end{array}$ & 6.3 & 5.1 & 16.5 & 9.5 & 9.8 & 9.1 \\
\hline
\end{tabular}

The analysis of the survey's results shows that effective implementation requires political and democratic resources to be deployed in the national education systems. A "top-down" approach needs to be embedded in good governance patterns, while the "bottom-up" approach necessitates a multitude of opportunities for participation by civil society. This is because education based on the sustainability model must go beyond 
environmental, economic and social issues (Ohlmeier, 2013, p. 8). Without considering politics and civil society, ESD will ultimately fall short. Imposed from above, it will fail to anchor itself in individual awareness and will ignore the creative potential of individual and civil society to help to shape the policy, which is indispensable for building a sustainable world. A successful educational policy for SD must aim to create educated and engaged citizens who are able to think about SD locally and globally.

\section{The Concept of Global Learning}

Much of what is known about the environment and about human use of nature and ecosystems, is likely to be out of date in few years' time or has to be changed. Applying such outdated knowledge may even be considered to be harmful. Teaching environmental knowledge must, therefore, be accompanied by a sense of relativity and uncertainty about the future. This may not really be compatible with the way learning has been organised in recent times. It seems to be necessary to rethink and redefine learning, a process that is determined by challenging knowledge that seems to be indisputable (Brunold, 2005, p. 4). In doing so an awareness of the uncertainty of knowledge about the environment would become an educational aim. The natural environment can only seem precious to those who know it and who have some direct experience of it. The extent to which the natural environment is ignored, and omitted from everyday experience and perhaps even replaced by virtual realities, is no longer in touch with veracity. The consideration of consumer buying habits and needs in the industrialised nations of the western world constitute an essential aspect of the subject.

Global learning, as one of the main concepts of education for sustainable development, has to be seen as a mediation of this perspective, which establishes connections between everyday observable problems, worldwide processes, and lines of conflicts. These connections are not generally obvious, but by making them overt, such an approach extends beyond national interests and is involved in social and political developments that are coherent in a global space within which there are pedagogical possibilities for action and reaction. Therefore, global learning is an extension or an amplification of the horizon of education, and the results of the globalisation process is to use interdisciplinary methods.

In the twenty-first century, the concept of global learning is being increasingly discussed and developed in the area of environmental policies and practices. In the further advancement of the concept of global learning, the area of global hazards is seen as a central point of view for the future development of humankind. As common indicators of all global hazards can be recognised, it is clear that as they go beyond national frontiers, the majority of people living in endangered areas are likely to be affected, and decisions about them will also affect future generations.

One of the substantial and important tasks for global learning therefore, is the transportation of knowledge, abilities and the preparedness for a constructive acting out of conflicts, and as a consequence to prepare appropriate programs (Gugel \& Jäger, 1997). For an appropriate adaptation of the subject of global learning there are necessarily very substantial efforts to be made in the area of political education, which has a key position in the pathway of effecting sustainability (Bundesministerium für wirtschaftliche Zusammenarbeit und Entwicklung, 1992; WBGU, 1996). 
Since the 1970s, there has been a consensus that political education should provide an important part in the solution through a variety of environmental and development problems (Deutscher Bundestag, 1972). Such considerations have also changed the theoretical implications and didactical models in the area of education that is concerned with environmental and development issues (Erdmann \& Wehner, 1996, p. 151).

While in the decades of the 1950s and 1960s theoretical aspects of education were present in the foreground, which was characterised by a formal orientation towards information, the 1970s promoted a curriculum theory where educational objectives were designed and formulated in a new way. Certain models were widely implemented by the defaulting of particular governments with respect to their policy in the area of development.

In the past decades, cognitive educational structures have been most prominent in the foreground, whereas the 1980s gave greater attention to and a perception of more active participatory methods of learning.

Increasingly, it has become evident that the terminus of the Third World is in need of a new access road, which would be more equitable and would involve a large number of problems and associated new developments within this multi-perspective field of politics. It is suggested then, that in the field of developmental pedagogy, learning about the Third World should no longer represent a central educational objective, but that learning with and from the Third World should be the centre of all didactic learning and instruction. As a consequence, there is no longer an interest in the existence of a Third World which must be considered obsolete, since it has been replaced by an awareness of 'One World' (Brunold, 2004). The One World concept highlights differentiation instead of homogeneity, and an equality of nations in addressing all questions about the future coverage of issues involving global rescues. Such a model signifies spatial, objective, and social dimensions and is also placed in the context of circumstances set in time and involving a modified model in development policies. Table 3 shows a modified model of global change that is a breakdown of these dimensions with respect to future problemsolving.

Table 3.

A modified model of global change (Source: Seitz, 1998, pp. 55-70; Brunold, 2009a, p. 323)

\begin{tabular}{lllll}
\hline & Characteristic & $\begin{array}{c}\text { Cognitive } \\
\text { presentation of } \\
\text { problems }\end{array}$ & \multicolumn{1}{c}{ Competence } & \multicolumn{1}{c}{$\begin{array}{c}\text { Modes of } \\
\text { learning }\end{array}$} \\
\hline $\begin{array}{l}\text { Spatial } \\
\text { dimension }\end{array}$ & Global space & Transparency & $\begin{array}{l}\text { Horizontal } \\
\text { expansion }\end{array}$ & $\begin{array}{l}\text { Global } \\
\text { learning }\end{array}$ \\
\hline $\begin{array}{l}\text { Factual } \\
\text { dimension }\end{array}$ & Complexity & $\begin{array}{l}\text { Contingency, } \\
\text { Interdependence, } \\
\text { Multi causal issues }\end{array}$ & $\begin{array}{l}\text { Ability to abstract and } \\
\text { multi causal thinking }\end{array}$ & $\begin{array}{l}\text { Systemic } \\
\text { learning }\end{array}$ \\
\hline $\begin{array}{l}\text { Temporal } \\
\text { dimension }\end{array}$ & $\begin{array}{l}\text { Dynamics and } \\
\text { relativity }\end{array}$ & Risk, nonlinearity & $\begin{array}{l}\text { Thinking in alternative } \\
\text { forms of acting and } \\
\text { time, reflection }\end{array}$ & $\begin{array}{l}\text { Anticipatory } \\
\text { learning }\end{array}$ \\
\hline $\begin{array}{l}\text { Social } \\
\text { dimension }\end{array}$ & $\begin{array}{l}\text { Multicultu- } \\
\text { ralism }\end{array}$ & Relativity & $\begin{array}{l}\text { Changing the perspec- } \\
\text { tive, empathy, tolerance, } \\
\text { participation }\end{array}$ & $\begin{array}{l}\text { Inter- and trans- } \\
\text { cultural learning }\end{array}$ \\
\hline
\end{tabular}


While driven by a traditional understanding of both learning and education, knowledge has been accumulating additively and this principle corresponds to the ideal of a time in which mechanisms of cause and effect do not have to be considered as key global problems. However, today's society seems to lack knowledge and orientation because of the vast amount of information that society requires. In the past the supply of knowledge remained valid for a relatively long period of time and lengthy periods of time passed before important discoveries in economy and technology impacted on society and culture (UNESCO-Document 25 C4, 1991, p. 27). Knowledge that was acquired during one's youth used to be sufficient for a whole life time. This has changed completely over recent years. Growing specialisation is necessary to administer, convey and use knowledge, and results in the fact that the individual takes a smaller and smaller part in society's collective knowledge (Fietkau, 1984, p. 24).

This paper suggests that global learning is gaining new value, since the speed at which knowledge becomes outdated has to lead to new modes of learning. The difficulty of thinking in terms of cybernetic models or in imagining scenarios shows that human beings are still conditioned to their immediate surroundings because of their genetic endowment. Learning by simulating and thinking in networks, however, is indispensable whenever the consequences of human actions need to be anticipated and developments made future-compliant (Weinbrenner, 1997, p. 122-151).

Thus the 'One World Education' is a form of political education that must not be neglected, since it includes the idea that it is the industrialised nations, above all, that are the main cause of environmental and developmental deficits, that they should take the first step to overcome these facts.

It has long been acknowledged that responsible behaviour towards the environment can neither be exclusively supported by a change of values and attitudes that are relevant for the environment nor exclusively by knowledge that is relevant for the environment. Behind this is the supposition that more environmental knowledge may lead to more environmental awareness, which is again a prerequisite for learning environmentally appropriate behaviour.

This premise is still alive because environmental education is dominated by the sciences, which have difficulty in giving up the thought that interpreting the ecology of natural balance correctly and logically leads to the most appropriate or 'right' behaviour with respect to environmental issues.

Compared with this, the result of research into environmental awareness can be reduced to the formula that no strong connection between environmental knowledge, attitudes towards the environment and environmental behaviour can be proved (Brunold, 2006, p. 227). Nevertheless, strengthening a population's environmental awareness is considered to be the central task for the future (WBGU, 1996, p. 3).

\section{Consequences for Civic Education for Sustainable Development}

Few political objectives areas are dependent on successful international cooperation. The basic conditions for education for sustainable development, however, differ considerably around the world. The same is true for educational approaches. More basic education as it is currently taught will not create more sustainable societies. The conundrum remains, that it is educated nations that leave the deepest ecological footprints, using the largest amounts of resources and energy to support their lifestyles. 
Sustainability in developing countries may mean something different than it would in an industrialised country or at least the political priorities would differ. In such countries, the immediate focus is on ensuring basic living conditions, whereas in industrial countries issues of sustainable consumption with regard to energy-inefficient luxury goods may be considered to be more important. It is also necessary to consider the challenge posed by so-called emerging economies to the sustainable development of world society. This raises some questions that go to the heart of the globalisation debate. What structures of global governance do we need in order to secure a viable future for the world? How do we allow developing countries to industrialise without endangering world climate? To what extent are scarcer resources and peacekeeping related (Leicht, 2005, p. 31)?

To develop public understanding and awareness of sustainability and to make progress towards more sustainable societies requires a population that is aware of the goals of sustainability and has the knowledge and the skills to contribute towards those goals. A knowledgeable citizenry supports a more sustainable society in several ways. First, citizens through their daily activities support government policy related to resource management and civic conduct. Second, citizens can support measures related to sustainable development and politicians who introduce and support enlightened legislation. Third, citizens can become knowledgeable consumers who purchase goods with low lifestyle impacts and who use their purchasing power to support corporate social and environmental responsibility and sustainable business practices. An informed citizenry can help communities and governments enact sustainability measures and move towards more sustainable societies.

Developing a knowledgeable citizenry requires a concerted effort with consistent and realistic messages delivered to people of all ages. The use of large scale media campaigns can reach substantial segments of society. Also, social marketing could be explored to deliver some of the simpler measures that lead to behavioural change. More comprehensive educational tools that focus on the skills inherent in critical thinking and rational decision making are necessary to build a citizenry capable of thinking through some of the more complex sustainability issues that face communities and nations (UNESCO, 2005b, Annex II, p. 5).

It is clear that towards participating for more sustainable societies an active citizenry also needs knowledge and skills regarding democratic citizenship. For this task an education for democratic citizenship would be capable as a specific and basic educational tool. An approach to education for democratic citizenship should aim for the promotion of a culture of democracy and human rights concerning goals like participation, social cohesion or solidarity as well as practices to promote the development of communities committed to genuine relationships. Civic education for sustainable development combines both education for sustainable development and education for democratic citizenship.

\section{Competencies for Education for Sustainable Development}

According to a quick change of knowledge and the focus on lifelong learning, education for sustainable development aims at acquiring competencies to be able to form the future actively and independently. In this context rational, emotional as well as activity-related components and the ability to evaluate are relevant. In relation to education for sustainable development the competencies focus on operating with know- 
ledge about sustainable development and recognising problems of non-sustainable development. According to de Haan there are eight competencies (de Haan, 2004, p. 3946) which however - in relation to civic education - can be modified and specified to a model of political-democratic civil competencies (Brunold, 2009a, p. 318). They are:

1) the competency to recognize and evaluate forms and conflicts of aims of political, economic, ecological and social 'value orientation' and their interests, as well as being able to act upon it,

2) the competency to develop skills of participation and intervention for their own interests and interests related to the common welfare, as well as being able to act upon it,

3) the competency to engage in the civil society and civic involvement in democracy,

4) the competency to percept global challenges from multiple perspectives,

5) the competency to perceive human and civil rights and be able to represent them actively,

6) the ability to understand and form the link between local experiences and their global context in the global society,

7) the competency to anticipate future risks and reflect the individual and global alternatives of acting and taking the responsibility of it, and

8) the competency to reflect the individual and cultural models which are provided by the media as well as to reflect consumption patterns and life styles as a political mature citizen.

To follow these political-democratic civil competencies it is useful to look at components and structural levels of development, which are integrated by a model of four components of development and a model of structural or action levels from the individual to the world level.

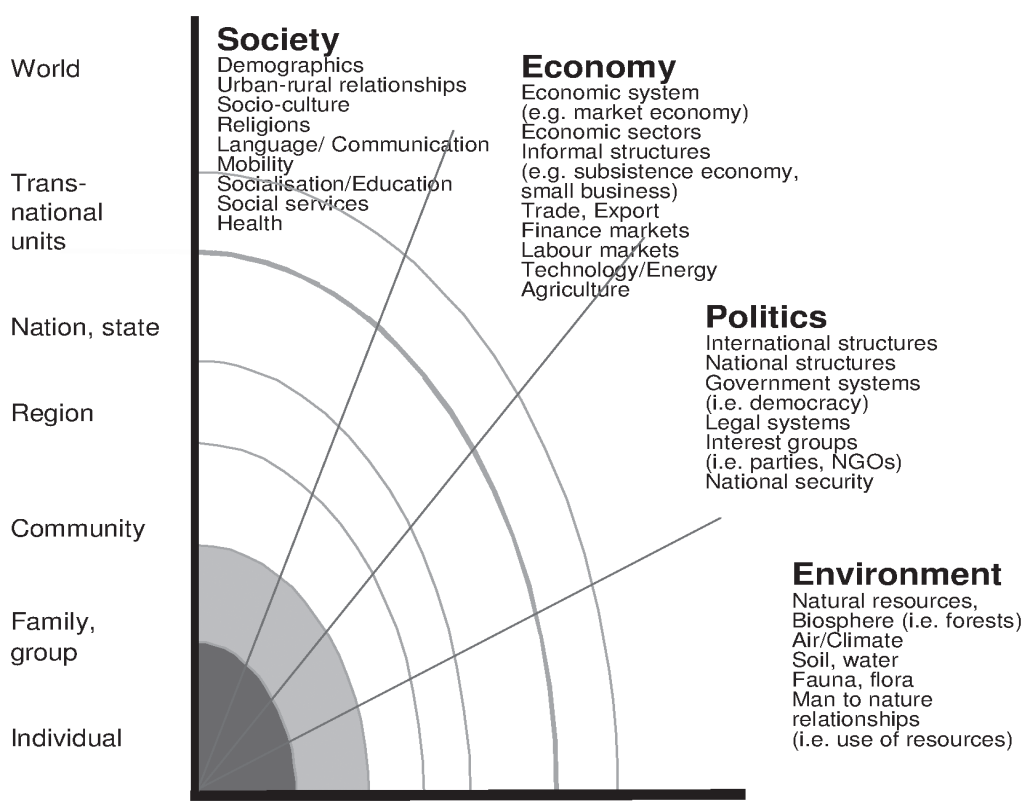

Figure 2. Components and structural levels of development (Source: Federal Ministry of economic cooperation and development, 2007, p. 26) 
Up until now globalization topics were taught in secondary school subjects (e.g. in Geography, Politics, History) without achieving real coherence. This lack of coherence at school level also represents the conflict of goals between the components of development. For example, the goals of ecological sustainability cannot simply meet the goals of economic productivity goals without further effort. The potential conflict and rapid shift in development processes illustrate the need to structure the complexity of global development.

Figure 3 shows the components of development with their most important tasks and objectives. The arrows indicate the areas of tension and conflicting goals between each pair of development components.

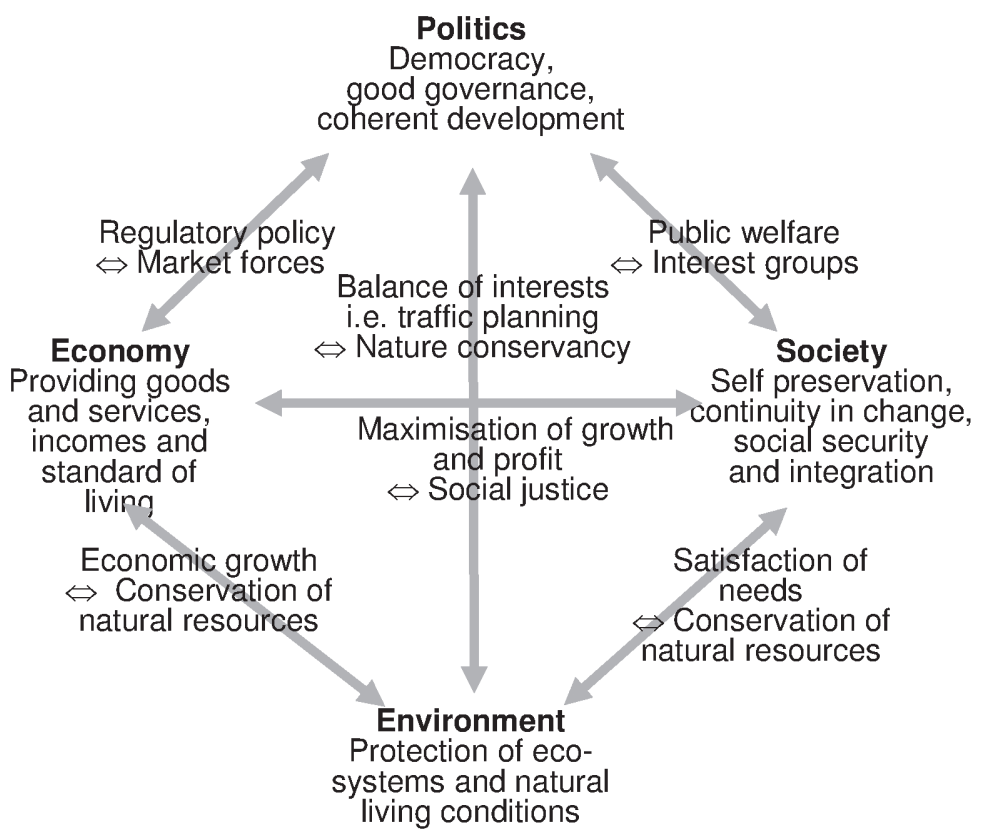

Figure 3. Conflicts of goals between development components (Source: Federal Ministry of economic cooperation and development, 2007, p. 30)

For this analytical purpose the framework deducts the four components shown above and various structural levels of development from the resolutions of the World Summits on sustainable development. They opted for more long-term coherence between the components representing societal sectors and the environment. Based on this international consent, the framework also defines competencies describing the abilities and proficiencies the pupils and students should be acquiring.

Table 4 shows an extended model of competencies, regarding education for sustainable development with the focus on global learning from a specific political-didactic and educational-political perspective. This model of 11 core competencies and further 11 subject-related competencies is being structured by three main areas: recognizing the focus on acquiring knowledge, evaluating the focus on reflection and at last acting with the focus on the ability and willingness to take an active part in society. 
Table 4

A Modified Model of Competencies for Education for Sustainable Development (Sources: Federal Ministry of economic cooperation and development, 2007, pp. 57-61, enlarged by Brunold)

\begin{tabular}{|c|c|c|}
\hline & Core competencies & Subject related competencies \\
\hline 1 & 2 & 3 \\
\hline \multirow{4}{*}{ 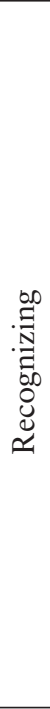 } & $\begin{array}{l}\text { Acquisition and processing } \\
\text { of information }\end{array}$ & $\begin{array}{l}\text { - Gather information on globalisation and development } \\
\text { issues and process them thematically }\end{array}$ \\
\hline & Recognition of diversity & $\begin{array}{l}\text { - Recognize socio-cultural and natural diversity in a } \\
\text { globalised world }\end{array}$ \\
\hline & $\begin{array}{l}\text { Analysis of global change, } \\
\text { globalization and develop- } \\
\text { ment processes according to } \\
\text { the principles of sustainable } \\
\text { development }\end{array}$ & $\begin{array}{l}\text { - Reflect on relations between politics, economy, society } \\
\text { and environment } \\
\text { - Recognize the conflicts between political, economic, } \\
\text { ecological and social interests in a multiperspective way } \\
\text { - Anticipate future risks and reflect on individual and } \\
\text { global alternatives of individual responsibility } \\
\text { - Analyse globalisation and development processes ap- } \\
\text { plying the guiding principle of sustainable development }\end{array}$ \\
\hline & $\begin{array}{l}\text { Differentiation between } \\
\text { structural levels and levels } \\
\text { of social action }\end{array}$ & $\begin{array}{l}\text { - Explain political participation possibilities of individuals } \\
\text { - Recognize the role of political actors regarding sustain- } \\
\text { ability goals } \\
\text { Recognize different structural levels from the individual } \\
\text { to the global and identify their respective functions for } \\
\text { development processes }\end{array}$ \\
\hline \multirow{3}{*}{ 总 } & $\begin{array}{l}\text { Change and shift of per- } \\
\text { spective and empathy; } \\
\text { Awareness for appreciation } \\
\text { and reflection of different } \\
\text { value orientations in their } \\
\text { significance for life }\end{array}$ & $\begin{array}{l}\text { - Perceive and anticipate own and other interests } \\
\text { - Evaluate interests according to political values } \\
\text { - Reflect on forms and conflicts of aims of political, } \\
\text { economic, ecological and social value orientation and } \\
\text { its interests } \\
\text { - Contemplate own and unfamiliar value orientations in } \\
\text { their greater meaning for life choices }\end{array}$ \\
\hline & $\begin{array}{l}\text { Critical reflection and } \\
\text { formation of opinion, } \\
\text { regarding questions of } \\
\text { globalization and the } \\
\text { principles of sustainable } \\
\text { development and human } \\
\text { rights }\end{array}$ & $\begin{array}{l}\text { - Know about the relevance of Good Governance for } \\
\text { sustainable development } \\
\text { - Justify human rights and reflect their inherent tensions } \\
\text { - Reflect on individual and cultural concepts as well as on } \\
\text { consumption habits and life styles, which are provided } \\
\text { by the media (evaluate as a politically mature citizen) } \\
\text { - Form opinions and simultaneously orient these opinions } \\
\text { to the international consensus on sustainable develop- } \\
\text { ment and human rights, contemplate critically about } \\
\text { globalisation and development issues. }\end{array}$ \\
\hline & $\begin{array}{l}\text { Assessment of development } \\
\text { aid measures, taking into } \\
\text { account different interests } \\
\text { and conditions }\end{array}$ & $\begin{array}{l}\text { - Recognize effects of political and juridical measures and } \\
\text { evaluate them in relation to sustainable development } \\
\text { - Develop tactics to assess development aid measures and } \\
\text { come to independent evaluations allowing for diverse } \\
\text { interests and determining factors }\end{array}$ \\
\hline
\end{tabular}


Sequel to Table 4.

\begin{tabular}{|c|c|c|}
\hline 1 & 2 & 3 \\
\hline \multirow{4}{*}{$\cdot \underbrace{\infty}_{0}$} & $\begin{array}{l}\text { Solidarity and co-responsi- } \\
\text { bilityas a challenge }\end{array}$ & $\begin{array}{l}\text { - Perceive the relevance of sustainable development (also } \\
\text { for globalization processes) and develop the ability and } \\
\text { motivation for responsible political acting } \\
\text { - Recognize areas of personal co-responsibility for man- } \\
\text { kind and the environment and accept the challenge }\end{array}$ \\
\hline & $\begin{array}{l}\text { Comn } \\
\text { confli }\end{array}$ & $\begin{array}{l}\text { - Appreciate the sense of human rights and represent } \\
\text { actively human and civil rights } \\
\text { - Endure cultural differences and differences of interests } \\
\text { - Contribute to the balance of interests and to conflict } \\
\text { resolutions } \\
\text { - Overcome socio-cultural and interest-related obstacles } \\
\text { and barriers in communication, cooperation and conflict } \\
\text { management }\end{array}$ \\
\hline & $\begin{array}{l}\text { Capacity to act on global } \\
\text { change; } \\
\text { Cooperation and motivation } \\
\text { to innovate personal and } \\
\text { job-related areas }\end{array}$ & $\begin{array}{l}\text { Ensure society's ability to act on global change, espe- } \\
\text { cially on a personal and professional level, through } \\
\text { openness and a willingness to innovate as well as } \\
\text { through a reasonable reduction of complexity and be } \\
\text { able to tolerate the uncertainty of open-ended situations }\end{array}$ \\
\hline & $\begin{array}{l}\text { Participation and active } \\
\text { involvement; } \\
\text { Activity in implementing } \\
\text { the principles of sustainable } \\
\text { development in the private, } \\
\text { school and job-related area } \\
\text { as well as on political and } \\
\text { social levels }\end{array}$ & $\begin{array}{l}\text { - Develop skills of participation and intervention for own } \\
\text { interests and interests of public welfare } \\
\text { - Support school children and students to enable them to } \\
\text { make their own political mature decisions and promote } \\
\text { the goals of sustainable development in their private, } \\
\text { school and professional lives to take an active role in } \\
\text { putting them into practice on a social and political level }\end{array}$ \\
\hline
\end{tabular}

\section{Thematic Areas and Choosing Topics in Curricula of Sustainable Development Education}

Global development education is integrated into the syllabi of many subjects. A variety of topics are covered from subject-specific perspectives as well as interdisciplinary or cross-disciplinary approaches in development education, environmental education, one world education or global learning projects. These learning areas can all be subsumed under the topic of Sustainable Development Education. In light of the contemporary nature and focus of the topics chosen, the thematic content is usually in the foreground. The skills and knowledge thus gained are important in and of themselves, but they remain fragmented, and connections are not automatically made to the competencies that could be drawn on in order to solve problems in variable situations (Federal Ministry of economic cooperation and development, 2007, p. 62).

Whereas the number of competencies to be learned is limited, and subject only to gradual changes in the course of societal transformation processes, this is not true of the topics covered in the learning area of Global Development. Competencies can only be developed situationally, or in studying concrete topics and doing concrete assignments of a seemingly infinite number, which are also often quickly obsolete. For this reason, thematic areas allow educators to create learning situations in which certain competencies can be developed. 
As in choosing competencies, the selection of thematic areas is a compromise to satisfy diverse criteria. Thematic areas are constructed according to a context model, such as is applied in many fields, whereby specific content is put into a context that is meaningful for the student. The content is made up of issues drawn from daily life, science and society that are relevant to students and to society. Analogous to the underlying concepts of the subjects involved, a particular focus is on the fundamental concepts of Global Development education, the guiding principle of sustainable development, the model of structural levels as well as diversity and shifting perspectives. Therefore thematic areas should:

- represent basic knowledge relevant to the learning area,

- illustrate the multidimensional character of the guiding principle of sustainable development,

- sufficiently represent the development perspective of this learning area,

- at the same time be relevant to students' lives and make a global perspective possible,

- be grouped in a manner usual in academic or social discourse,

- draw from teaching experience.

From these thematic areas, within the framework of the school curricula, topics can be chosen for the creation of assignments and the design of learning situations depending on the options for implementation within the subjects involved or interdisciplinary project. These topics should offer students an opportunity to develop competencies in this learning area and fulfil specific performance requirements. Therefore the following proposed list of twenty thematic areas, to be addressed in the classroom, is not complete and can be developed further as long as the above-mentioned criteria are met (Federal Ministry of economic cooperation and development, 2007, p. 63).

1) Diversity of values, cultures and living conditions;

2) Globalisation of religious and ethical guiding principles;

3) History of globalisation: From colonialism to the "global village";

4) Commodities from around the world: Production, trade and consumption;

5) Food and agriculture;

6) Illness and health;

7) Education;

8) Globalised leisure-time activities;

9) Protection and use of natural resources and energy production;

10) Opportunities and dangers of technological progress;

11) Global environmental changes;

12) Mobility, urban development and traffic;

13) Globalisation of the economy and labour;

14) Demographic structures and developments;

15) Poverty and social security;

16) Peace and conflict;

17) Immigration and integration;

18) Political power, democracy and human rights (Good governance);

19) Development cooperation and institutions;

20) Global governance - World order. 


\section{Conclusions}

All sectors, including business, industry, government, non-governmental organisations, community organizations and higher education, should be encouraged to train their leaders in sustainability issues such as environmental management, equity policies, and to provide training to their workers in sustainable practices. The development of specialised training programmes to ensure that all sectors of the workforce have the knowledge and skills necessary to perform their work in a sustainable manner is a critical component of education for sustainable development.

Higher education institutions like universities are predestined initiating sustainable development, because an individual change of consciousness assumes specific governmental politics and educational institutions that are able to push these changing processes. A viable possibility for higher education institutions is to train people in sustainability and to implement a multidisciplinary and competency-related master program relating to Education for Sustainable Development. The main target groups of the master program may be teachers, social workers as well as administrative and governmental officials who fill the key and multiplier positions in society. With the focus on these target groups a Master's program could contribute in particular to strengthen the link between schools and the community which is barely pronounced both in industrialized and developing countries. Educated in the same content and methods, teachers and social workers and administrative officials should initiate and consolidate stable and coordinated collaborations in the same projects and contents. These common acts should strengthen the social cohesion in the school community. The module plans for a master program containing interdisciplinary approaches should consist the following sub disciplines: Political and social sciences for good governance issues, economics for consumer issues and sustainable economical acting, Sociology, Law for ecological, economical and social aspects of law, Ecological sciences and didactics and methodology for best-practice and case studies.

For developing specialised training and master programs it is necessary to support educational politics, and especially an 'ecological awareness' - both in the industrialised nations of the North and also in the developing countries of the South. The countries in the North should be aware of their exemplary function. It is an essential educational aim to show that sustainable and forward-looking development is not the responsibility of the 'Third World' in the first place and that developmental aid from the North to the South without changing behaviour in the North may have disastrous effects and do great harm.

However, no universal models of ESD exist. While there is an overall agreement on the principles and supporting concepts of sustainability, slight differences exist depending on local contexts, priorities, and approaches. Each country has to define its own educational priorities and actions required for sustainability. The goals, emphases and processes must, therefore, be locally defined to meet the local political, environmental, social and economic conditions in culturally appropriate ways. Education for sustainable development is equally relevant and important for both developed and developing countries, but it shows that civic education for sustainable development must aim to produce informed and empowered global citizens (Ohlmeier 2013, p. 5). 


\section{References}

Andersen, U., Homberger, I., \& Penedo, N. (1999). Lokale Agenda 21 und Entwicklungspolitik [Local agenda 21 and development policy]. In Politische Bildung. Entwicklung der Entwicklungspolitik, Jhrg. 32, Band 3, Schwalbach/Ts.: WochenschauVerlag, 30-38.

Brunold, A. (2004). Globales Lernen und Lokale Agenda 21. Aspekte kommunaler Bildungsprozesse in der 'Einen Welt' [Global learning and local Agenda 21. Aspects of local processes of education in "One world"]. Wiesbaden: VS-Verlag.

Brunold, A. (2005). Global Learning and Education for Sustainable Development. In Higher Education in Europe (UNESCO-CEPES), Quarterly Review, Vol. 30, Nos. 34, October - December 2005, Routledge - Taylor \& Francis Group, Abingdon (Great Britain) 2005, p. 295-306.

Brunold, A. (2006). The United Nations decade of education for sustainable development, its consequences for international political education, and the concept of global learning. In International Education Journal, 7(3), Shannon Research Press, pp. 222234.

Brunold, A. (2009a). Politische Bildung für nachhaltige Entwicklung und das Konzept des Globalen Lernens [Civic education for sustainable development and the concept of global learning]. In H. Oberreuter (Ed.), Standortbestimmung Politische Bildung [Positioning civic education] (pp. 307-333). Schwalbach/Ts.: Wochenschau-Verlag.

Brunold, A. (2009b). Politische Bildung für nachhaltige Entwicklung und die UN-Dekade der Bildung für nachhaltige Entwicklung [Civic education for sustainable development and the UN-decade of civic education for sustainable development]. In Schriftenreihe der Gesellschaft für Politikdidaktik und politische Jugend- und Erwachsenenbildung-GPJE (Ed.). Aktuelle theoretische und empirische Projekte in der Politikdidaktik, Band 8/2009 (pp. 68-83). Schwalbach/Ts.: Wochenschau-Verlag.

Bundesministerium für wirtschaftliche Zusammenarbeit und Entwicklung (BMZ) (Ed.) (1992). Umwelt und Entwicklung [Environment and development]. Bericht der Bundesregierung über die Konferenz der Vereinten Nationen für Umwelt und Entwicklung im Juni 1992 in Rio des Janeiro. Entwicklungspolitik, Materialien Nr. 84, BMZ Bonn.

Council of Europe (COE) (Ed.) (2003). A glossary of terms for Education for Democratic Citizenship. COE Strasbourg. Retrieved October 28, 2015, from http://www. edchreturkey-eu.coe.int/Source/Resources/Pack/GlossaryEDC_EN.pdf

De Haan, G. (2004). Politische Bildung für Nachhaltigkeit [Civic education for sustainability]. Aus Politik und Zeitgeschichte [From Politics to Contemporary History], B 7-8, Bonn, 39-46.

Deutscher Bundestag (Ed.) (1972). Umweltschutz [Environment protection].-Umweltprogramm der sozialliberalen Koalition 1971. Bundestagsdrucksache 6/2710, Printed matter of the German Bundestag 6/2710, Stuttgart.

Erdmann, K.H. \& Wehner, G. (1996). Die Bedeutung des Wissens für die Umwelt- und Naturschutzbildung [The importance of knowledge for environmental education]. In Erdmann, K.-H., Nauber, J. (Ed.). Beiträge zur Ökosystemforschung und Umwelterziehung, Band. III, MAB-Mitteilungen 38, Bonn, 151-163.

Federal Ministry of economic cooperation and development, Standing Conference of Ministers of Education and Cultural Affairs (KMK) (Eds.) (2007). A Cross-Cur- 
ricular Framework for Global Development Education in the Context of Education for Sustainable Development, KMK Bonn.

Fietkau, H.J. (1984). Bedingungen ökologischen Handelns. Gesellschaftliche Aufgaben der Umweltpsychologie, [Conditions of ecological action. Social tasks of environmental psychology], Weinheim: Beltz-Verlag.

Gugel, G. \& Jäger, U. (1997). Globales Lernen. Eine Perspektive zur friedenspädagogischen Bildungsarbeit, In W.-R. Vogt \& E. Jung, (Hrsg.): Kultur des Friedens. Wege zur Einen Welt, [Global learning. Perspective for a peace-educational formation. In W.R. Vogt \& E. Jung, (Eds.), Culture of Peace. Ways to One World], Darmstadt: Omnia-Verlag.

Hauff, V. (1987). Unsere gemeinsame Zukunft. Der Brundtland-Bericht der Weltkommission für Umwelt und Entwicklung, [Our common future. The Brundtland-Report of the World-Commission on Environment and Development], Greven: Eggenkamp Verlag.

Klafki, W. (1991). Neue Studien zur Bildungstheorie und Didaktik, [New studies about theory of education and didactics], Weinheim/Basel: Beltz-Verlag.

Leicht, A. (2005). Learning Sustainability - the UN Decade of Education for Sustainable Development in Germany. An International Education Initiative, In UNESCO today, 2/2005, Paris, 26-31.

Ohlmeier, B., \& Brunold, A. (2015). Politische Bildung für nachhaltige Entwicklungeine Evaluationsstudie [Civic education for sustainable development - an evaluation study]. Wiesbaden: Springer VS Research.

Ohlmeier, B. (2013). Civic education for sustainable development, In A. Skrinda (Ed.). Discourse and Communication for Sustainable Education, 4, 5-22.

Seitz, K. (1998). Globales Lernen - Bildungswende für eine Zukunftsfähige Entwicklung. In G. Führing (Hrsg.), Lernen in weltweitem Horizont, [Global Learning - Turnaround to a Education for Sustainable Development. In G. Führing (Ed.)], Learning in a World-Wide Horizon). Münster: Waxmann-Verlag.

UNESCO (Ed.) (1991). Dokument 25 C/4, Dritter mittelfristiger Plan 1990-1995, (UNESCO Document 25 C/4, Third medium-termed plan 1990-1995). UNESCO: Bonn.

UNESCO (Ed.) (2005a). United Nations Decade of Education for Sustainable Development 2005-2014, Draft International Implementation Scheme. UNESCO: Paris. Retrieved October 28, 2015, from http://unesdoc.unesco.org/images/0014/001486/ 148650E.pdf

UNESCO (Ed.) (2005b). Executive Board, 172 EX/11, Report by the Director-General on the United Nations Decade of Education for Sustainable Development. International Implementation Scheme and UNESCO's contribution to the Implementation of the Decade. UNESCO: Paris. Retrieved October 28, 2015, from http://unesdoc.unesco.org/images/0014/001423/142311E.pdf

United Nations (Ed.) (2014). General Assembly, Document A/68/970, Report of the Open Working Group of the General Assembly on Sustainable Development Goals, Sixty-eighth session, August 12, 2014. United Nations New York. Retrieved October 28, 2015, from https://sustainabledevelopment.un.org/content/documents/ 1579SDGs\%20Proposal.pdf

Weinbrenner, P. (1997). Didaktische und methodische Konzepte für die Bearbeitung ökologischer und zukunftsorientierter Themen. In S. Frech, E. Halder-Werdon \& 
M. Hug (Hrsg.), Natur - Kultur. Perspektiven ökologischer und politischer Bildung, [Didactical and methodological concepts for the treatment of ecological and futureoriented topics. In S. Frech, E. Halder-Werdon \& M. Hug (Eds.), Nature - Culture. Perspectives of ecological and political education]. Schwalbach/Taunus: Wochenschau-Verlag.

Wissenschaftlicher Beirat der Bundesregierung Globale Umweltveränderungen (WBGU) (1996). Welt im Wandel. Wege zur Lösung globaler Umweltprobleme. Jahresgutachten 1995, German Advisory Council on Global Environmental Change. [The World in Change. Ways to solve global environmental problems. Expert-Audit 1995]. Berlin: WBGU.

Wissenschaftlicher Beirat der Bundesregierung Globale Umweltveränderungen (WBGU) (1999). Welt im Wandel. Strategien zur Bewältigung globaler Umweltrisiken. German Advisory Council on Global Environmental Change. [The World in Change. Strategies to master global environmental risks]. Berlin: WBGU.

Correspondence concerning this paper should be addressed to Prof. Dr. Andreas Brunold, Civic Education and Civic Education Didactics, the University of Augsburg, Germany. Email: andreas.brunold@phil.uni-augsburg.de 